\title{
8. HEAT-FLOW RESULTS, DSDP LEG 48
}

\author{
A. J. Erickson ${ }^{1}$ and W. E. Avera, Geology Department, University of Georgia, Athens, Georgia \\ and \\ R. Byrne, ${ }^{2}$ Deep Sea Drilling Project, Scripps Institute of Oceanography, La Jolla, California
}

\section{METHODS AND TECHNIQUES}

Downhole temperatures were measured at various depths in holes drilled during Leg 48 using the same techniques and equipment discussed by Erickson et al. (1975). Briefly, a battery-operated, entirely self-contained temperature recorder is rigidly locked into the lower end of a standard wire-line core barrel with a steel thermistor probe protruding several decimeters ahead of the core cutter. The core barrel is lowered to the bottom of the drill string where the probe passes through the bit and is latched into the bottom-hole assembly. The drill string is then lowered slowly, pushing the probe ahead into the undrilled sediment, until the weight of the bottom-hole assembly is supported by the undrilled sediment. The probe is left in this position 15 minutes or so until it attains, or has at least approached, thermal equilibrium with the undrilled sediment, after which time it is pulled back up to the ship along with the core barrel. The entire process, which must be repeated each time a downhole temperature measurement is made, takes between one and two hours, depending on water depth and operating conditions.

The instrument is capable of recording temperature changes of $\pm 0.01^{\circ} \mathrm{C}$, and has an accuracy of $\pm 0.05^{\circ} \mathrm{C}$. The probable error which is relevant to a particular downhole temperature measurement is often much larger than the instrumental errors due to our inability to control the environment within which the temperature measurement is being made. Specifically, the effect of ship movement transmitted through the drill string, causing premature cooling and/or frictional heating as the probe is alternately inserted and withdrawn, inevitably produces temperatures which are not representative of the in-situ sediment temperature. Failure of the probe to penetrate the sediment, or penetration in a such a way as to allow cool water to reach the probe tip, will also result in the acquisition of nonrepresentative temperature data.

Thermal conductivity measurements were made aboard ship using the needle-probe technique described by Von Herzen and Maxwell (1959). The thermal conductivity values measured at laboratory temperature and pressure should, for maximum accuracy, be corrected to their in-situ values (Erickson, 1973), however, the corrections only amount to a few per cent and have been neglected in the following discussions.

'Present address: Eureka Resource Associates, Berkeley, California,

"Present address: 11361 Red Cedar Way, San Diego, Ca. 92131.

\section{RESULTS}

\section{Site $\mathbf{4 0 2}$}

Three downhole temperature measurements were made at Site 402, and a fourth in Hole 402A. The results of the measurements are listed in Table 1 and shown graphically in Figure 1. It is not obvious that the depth of 165.5 meters assumed for the measurement in Hole 402A can realistically be plotted on the same graph as the data from Hole 402 because a change in water depth due to the offset from Hole 402 to $402 \mathrm{~A}$ could introduce substantial error in the placement of the data point from Hole $402 \mathrm{~A}$ on Figure 1.

Although the curve shown in Figure 1 can hardly be described as "linear," it clearly defines a subnormal geothermal gradient. The quality of the temperature determinations varies immensely from the highly disturbed measurement at 51.5 meters sub-bottom (Figure 2a) to the almost ideal measurement at 130.5 meters sub-bottom (Figure 2c). Considering the disturbed characteristics of the measurements at 89.5 meters sub-bottom (Figure 2b), the "'kinked" nature of the temperature-depth plot shown in Figure 1 is not considered geologically significant.

Five thermal conductivity measurements were made at Site 402, one in sediment recovered from the first hole drilled at the site, and four in sediment from Hole 402A (Table 2). Using the mean of the five conductivity values and "best" straight line "eyeball" fit to the temperature-depth data plotted in Figure 1, a heat-flow value of $0.86 \pm 0.34 \mu \mathrm{cal} / \mathrm{cm}^{2} \mathrm{sec}$ is calculated for this site. Whereas there is a large percentage of probable error for this measurement, it appears certain that the maximum heat flow at this site is less than $1.2 \mu \mathrm{cal} / \mathrm{cm}^{2} \mathrm{sec}$, substantially lower than the mean ocean heat flow of $1.46 \mu \mathrm{cal} / \mathrm{cm}^{2} \mathrm{sec}$ (Von Herzen and Lee, 1969) and relatively close to the heat flow of $1.03 \mu \mathrm{cal} / \mathrm{cm}^{2} \mathrm{sec}$ expected (Parsons and Sclater, 1977, Equation 23), assuming lithospheric cooling for $120 \mathrm{~m}$.y. (see Site Chapter 4). The observation of a heat flow as low

TABLE 1

Downhole Temperature Data Obtained at Site 402

\begin{tabular}{lrrl}
\hline Hole & Depth $(\mathrm{m})$ & Temp $\left({ }^{\circ} \mathrm{C}\right)$ & \multicolumn{1}{c}{ Remarks } \\
\hline 402 & $0.0 \pm 5.0$ & $3.40 \pm 0.20$ & Measured in drill pipe \\
402 & $51.5 \pm 1.0$ & $4.85 \pm 0.20$ & Erratic cooling \\
402 & $89.5 \pm 1.0$ & $5.40 \pm 0.10$ & Moderately disturbed \\
402 & $130.5 \pm 1.0$ & $8.20 \pm 0.05$ & Excellent \\
$402 \mathrm{~A}$ & $165.5 \pm 5.0$ & $8.85 \pm 0.05$ & Excellent \\
\hline
\end{tabular}

Note: The depth of 165.5 meters for the measurement in Hole $402 \mathrm{~A}$ is predicated on the unverified assumption that the water depths at Holes 402 and $402 \mathrm{~A}$ were equal. 


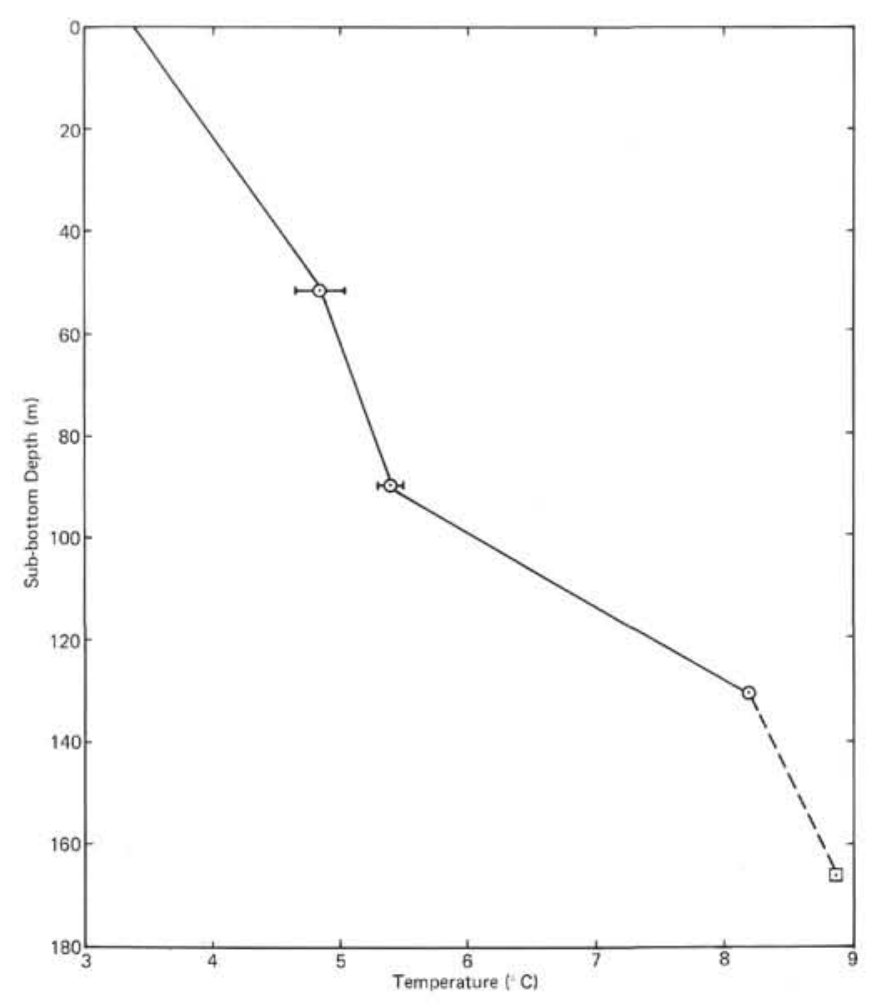

Figure 1. Plot of downhole temperature versus sub-bottom depth at DSDP Site 402. Downhole temperature measured in Hole $402 \mathrm{~A}$ is shown as a square, all other measurements (indicated by circles) were made in Hole 402.

as $0.86 \mu \mathrm{cal} / \mathrm{cm}^{2} \mathrm{sec}$ may be due to local environmental factors (topography and thermal refraction) associated with the location of the drill site in a submarine canyon. In conclusion, the low heat flow is consistent with hypotheses which consider this one of the oldest portions of the Atlantic Ocean.

\section{Site $\mathbf{4 0 3}$}

Downhole temperature measurements were made at five depths at Site 403 (Table 3). Most of the temperature-time records (Figures 3a-e) show varying degrees of disturbance but the deepest measurement (Figure $3 \mathrm{e}$ ) is of excellent quality, and four of the five data points define a nearly constant thermal gradient of $49.3 \pm 3.1^{\circ} \mathrm{C} / \mathrm{km}$ between 61.5 and 242.0 meters sub-bottom (Figure 4). A somewhat higher thermal gradient $\left(65.0 \pm 15.4^{\circ} \mathrm{C} / \mathrm{km}\right)$ was determined using the borehole temperature measurement at 61.5 meters sub-bottom and an estimate of the bottom water temperature measured in the drill pipe just as the heat-flow probe entered the borehole. The eight thermal conductivity measurements made at this site (Table 2) may best be treated by averaging the three values measured on sediment recovered from between 12.1 and 33.9 meters sub-bottom $(2.47 \pm 0.35$ $\mathrm{mcal} / \mathrm{cm}^{2} \mathrm{sec}^{\circ} \mathrm{C}$ ) and the five values determined on sediment recovered from 74.47 and 188.60 meters sub-bottom (3.09 $\pm 0.11 \mathrm{mcal} / \mathrm{cm}^{2} \mathrm{sec}^{\circ} \mathrm{C}$ ). Multiplication of these average conductivities by the thermal gradients determined over those intervals permits calculation of two interval heatflow values $\left(1.61 \pm 0.38\right.$ and $\left.1.52 \pm 0.10 \mu \mathrm{cal} / \mathrm{cm}^{2} \mathrm{sec}\right)$ for the upper and lower intervals, respectively. The value of 1.52 $\mu \mathrm{cal} / \mathrm{cm}^{2} \mathrm{sec}$ determined between 61.5 and 242.0 meters sub-bottom is considered to be the most reliable.

\section{Site 406}

Although five downhole temperature measurements were made at Site 406, it appears from the shape of the temperature-time records that only the uppermost two measurements (Figures 5a, b) provided a valid indication of in-situ sediment temperatures. The temperature-time records of the remaining three measurements (Figures $5 \mathrm{c}-\mathrm{e}$ ) show increasing tendencies to cool, rather than to attain a constant temperature, during the measurement interval. This failure to approach thermal equilibrium with the sediments is attributed to failure of the thermistor probe to penetrate the undrilled sediments in such a way as to prevent movement of water from the borehole towards the tip of the probe, probably as a consequence of the increasing induration of the sediment below 223.5 meters sub-bottom. For this reason, the most reliable thermal gradient is believed to be the value of $57.8 \pm 2.4^{\circ} \mathrm{C} / \mathrm{km}$ calculated using the results of the measurements at 71.5 and 147.5 meters sub-bottom (Table 4). Multiplication of this thermal gradient by the means of the two closest thermal conductivity measurements $\left(2.85 \pm 0.32 \mathrm{mcal} / \mathrm{cm} \mathrm{sec}{ }^{\circ} \mathrm{C}\right)$ at 65.85 and 216.15 meters gives a heat flow of $1.65 \pm 0.25$ $\mu \mathrm{cal} / \mathrm{cm}^{2} \mathrm{sec}$. Two other interval heat-flow values can be determined with less reliability if the thermal gradient is calculated using the temperature measured in the drill pipe just prior to the time that the temperature recorder was lowered into the borehole, and if the downhole temperature measurement at 223.5 meters sub-bottom is considered to be nearly unaffected by the cooling which appears to only have begun after 36 minutes (Figure 5c).

Using temperature values listed in Table 4, thermal gradients of $67.7 \pm 6.6$ and $51.2 \pm 2.7{ }^{\circ} \mathrm{C} / \mathrm{km}$ were calculated for the intervals 0 to 71.5 meters and 147.5 to 223.5 meters, respectively. Only a single thermal conductivity value is available within each of these intervals; however, using values of 2.53 and 3.17 $\mathrm{mcal} / \mathrm{cm}^{2} \mathrm{sec}{ }^{\circ} \mathrm{C}$ (Table 2) for the upper and lower intervals permits calculation of interval heat-flow values of 1.71 \pm 0.34 and $1.62 \pm 0.21 \mu \mathrm{cal} / \mathrm{cm}^{2} \mathrm{sec}$ for these intervals, respectively. The variation in the interval heat flow between the sea floor and 223.5 meters is not significant, and suggests that the amount of cooling evident in the temperature-time record shown in Figure 6 can be reasonably explained in terms of the normal downward increase in thermal conductivity. The heat flow at this site is best represented by the value of $1.65 \pm 0.25 \mu \mathrm{cal} / \mathrm{cm}^{2} \mathrm{sec}$ determined between 71.5 and 147.5 meters sub-bottom.

\section{CONCLUSIONS}

The results of the heat-flow determinations at Sites 402, 403 , and 406 are tabulated (Table 5). A heat flow of 0.86 $\mu \mathrm{cal} / \mathrm{cm}^{2} \mathrm{sec}$ was determined at Site 402 in a canyon on the northern continental margin of the Bay of Biscay north of the Meriadzek escarpment. The low heat-flow value 


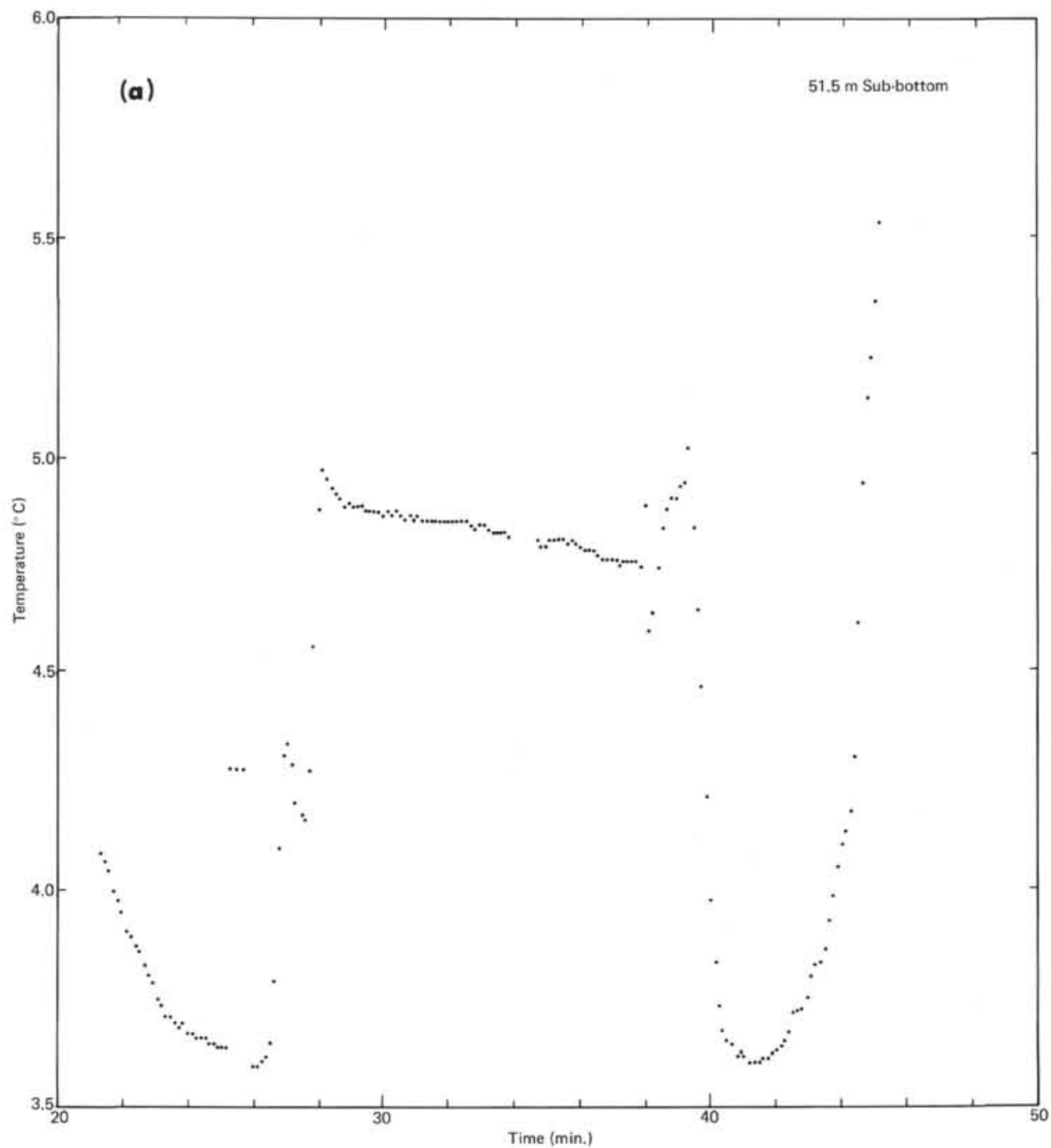

Figure 2. (a-d) Plot of recorded temperature versus time during the downhole temperature measurements at Site 402.

supports the idea that the amount of time since the margin formed by rifting is at least as large as the thermal time constant of the lithosphere $(\approx 100 \mathrm{~m} . \mathrm{y}$.), since the initial heat associated with the formation of the margin is no longer present.

Normal or slightly high heat-flow values were measured on the margins of the Rockall Plateau, believed to be a fragment or splinter of crustal material having continental composition and thickness (Roberts, 1971) and formed about 60 m.y. ago. The "cooling lithosphere" model presented by Parsons and Sclater (1977) suggests that a heat flow of about $1.46 \mu \mathrm{cal} / \mathrm{cm}^{2} \mathrm{sec}$ is expected through oceanic crust of this age. This is well within, but slightly lower than, the heat-flow values actually measured at Sites 403 and 406 . If the increased radiogenic heat production within the microcontinent can result in a general warming of the surrounding oceanic regions in the manner suggested by Long and Lowell (1973), then the fact that the effect is barely recognizable near the margins of the Rockall Plateau suggests that the radiogenic content of the material beneath the plateau may be lower than that normally considered characteristic of "continental" material.

\section{REFERENCES}

Erickson, A., 1973. Initial report on downhole temperature and shipboard thermal conductivity measurements, Leg 19, Deep Sea Drilling Project. In Creager, J. S., Scholl, D. W., et al., Initial Reports of the Deep Sea Drilling Project, v. 19: Washington (U.S. Government Printing Office), p. 643-656.

Erickson, A. J., Von Herzen, R. P., Sclater, J. G., Girdler, R. W., Marshall, B. V., and Hyndman, R., 1975. Geothermal measurements in deep-sea drill holes, J. Geophys. Res., v. 80, p. $2515-2528$.

Long, L. T. and Lowell, R. P., 1973. Thermal model for some continental margin sedimentary basins and uplift zones, Geology, v. 1, p. 87-88.

Parsons, B. and Sclater, J. G., 1977. An analysis of ocean floor bathymetry and heat flow with age, J. Geophys. Res., v. 82, p. 803-827. 


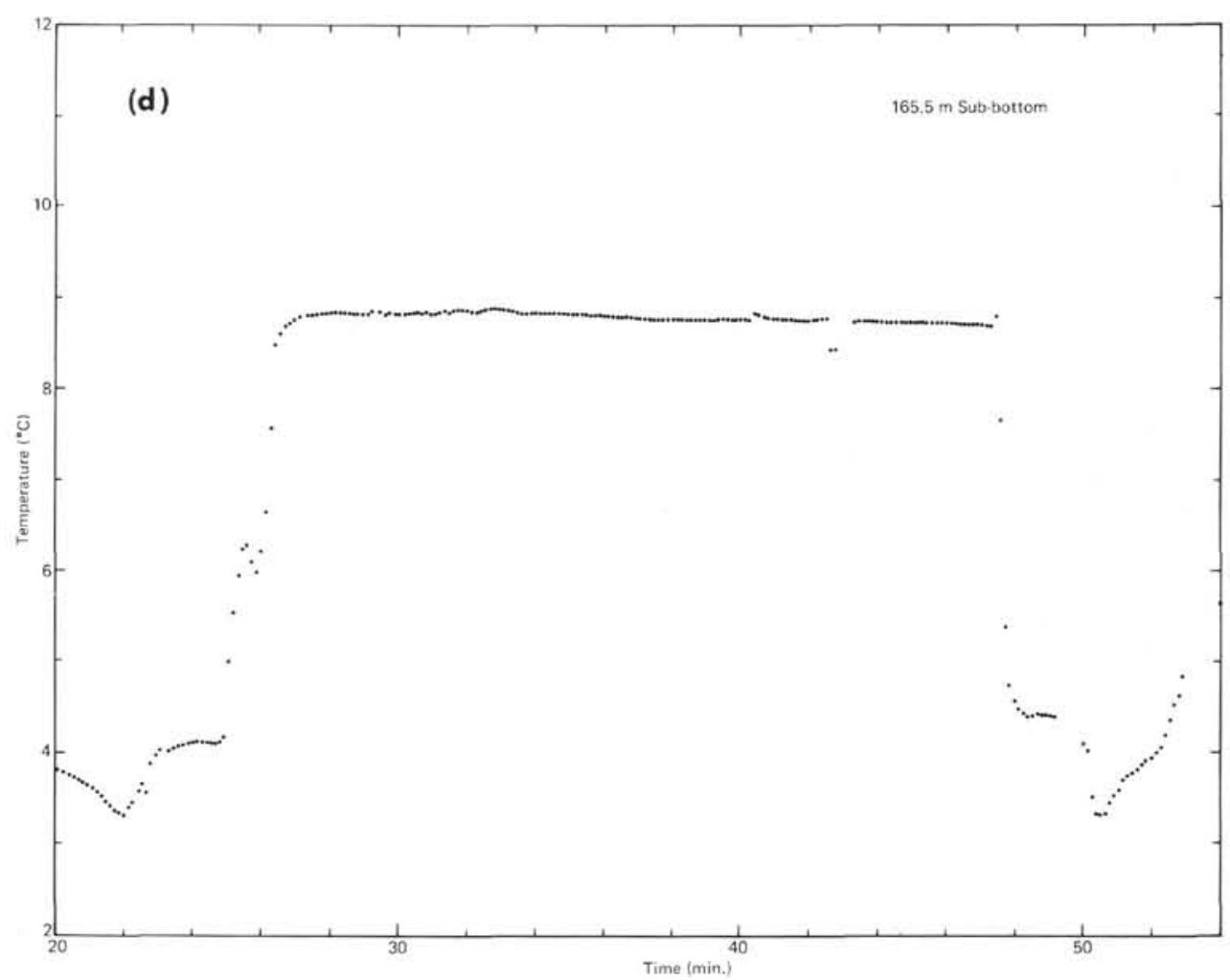

Figure 2. Continued.

TABLE 2

Thermal Conductivity Data Measured Aboard Ship During DSDP Leg 48

\begin{tabular}{lcc}
\hline $\begin{array}{c}\text { Sample } \\
\text { (Interval in cm) }\end{array}$ & $\begin{array}{c}\text { Sub-Bottom } \\
\text { Depth (m) }\end{array}$ & $\begin{array}{c}\text { Conductivity } \\
\left.\text { (mcal/cm } \text { sec }^{\circ} \mathrm{C}\right)\end{array}$ \\
\hline $402-1,3-63$ & 3.63 & 3.31 \\
$402 \mathrm{~A}-1,6-63$ & 145.13 & 3.04 \\
$402 \mathrm{~A}-1,6-107$ & 145.57 & 3.07 \\
$402 \mathrm{~A}-3,6-122$ & 164.72 & 2.89 \\
$402 \mathrm{~A}-4,6-60$ & $(173.60)$ & 2.78 \\
$403-2,6-60$ & 12.10 & 2.17 \\
$403-2,6-110$ & 12.60 & 2.27 \\
$403-5,1-90$ & 33.90 & 2.96 \\
$403-8,5-97$ & 74.47 & 2.99 \\
$403-9,4-92$ & 76.42 & 2.98 \\
$403-17,2-35$ & 148.85 & 3.03 \\
$403-18,2-60$ & 158.60 & 3.27 \\
$403-21,3-60$ & 188.60 & 3.16 \\
$406-2,3-85$ & 65.85 & 2.53 \\
$406-4,1-65$ & 216.15 & 3.17 \\
$406-8,5-62$ & 353.62 & 3.30 \\
\hline
\end{tabular}

Note: The sub-bottom depth in parentheses is not in agreement with other records and is probably incorrect.
TABLE 3

Downhole Temperature Data Obtained in Hole 403

\begin{tabular}{rrl}
\hline Depth $(\mathrm{m})$ & Temp. $\left({ }^{\circ} \mathrm{C}\right)$ & \multicolumn{1}{c}{ Remarks } \\
\hline $0.0 \pm 5.0$ & $3.02 \pm 0.05$ & Measured in drill pipe \\
$61.5 \pm 5.0$ & $7.05 \pm 0.50$ & Variable - ship drifted off site \\
$99.5 \pm 1.0$ & $7.00 \pm 0.50$ & Bit sinking during measurement \\
$147.0 \pm 1.0$ & $11.25 \pm 0.25$ & Disturbed \\
$194.5 \pm 1.0$ & $13.60 \pm 0.10$ & Slightly disturbed \\
$242.0 \pm 1.0$ & $15.95 \pm 0.05$ & Excellent \\
\hline
\end{tabular}

Roberts, D. G., 1971. New geophysical evidence on the origins of the Rockall Plateau and Trough, Deep-Sea Res., v. 18, p. 353-360.

Von Herzen, R. P. and Lee, W. H. K., 1969. Heat flow in oceanic regions. In Hart, P. J. (Ed.), The earth's crust and upper mantle, geophysical monogr. 13: Washington (American Geophysical Union), p. 88-95.

Von Herzen, R. P. and Maxwell, A. E., 1959. The measurement of thermal conductivity of deep-sea sediments by a needle-probe method, J. Geophys. Res., v. 64, p. 1557-1563. 


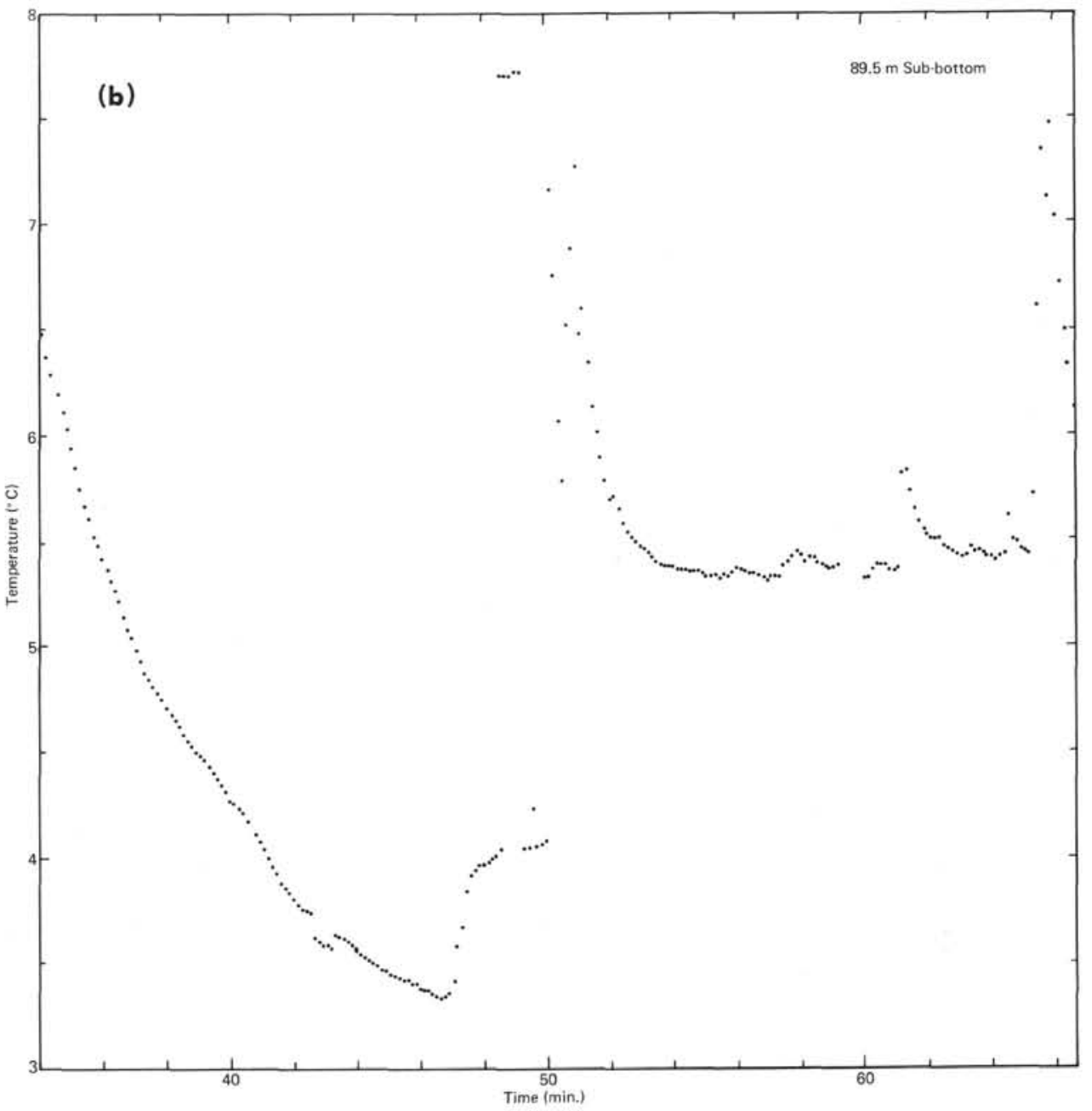

Figure 2. Continued.

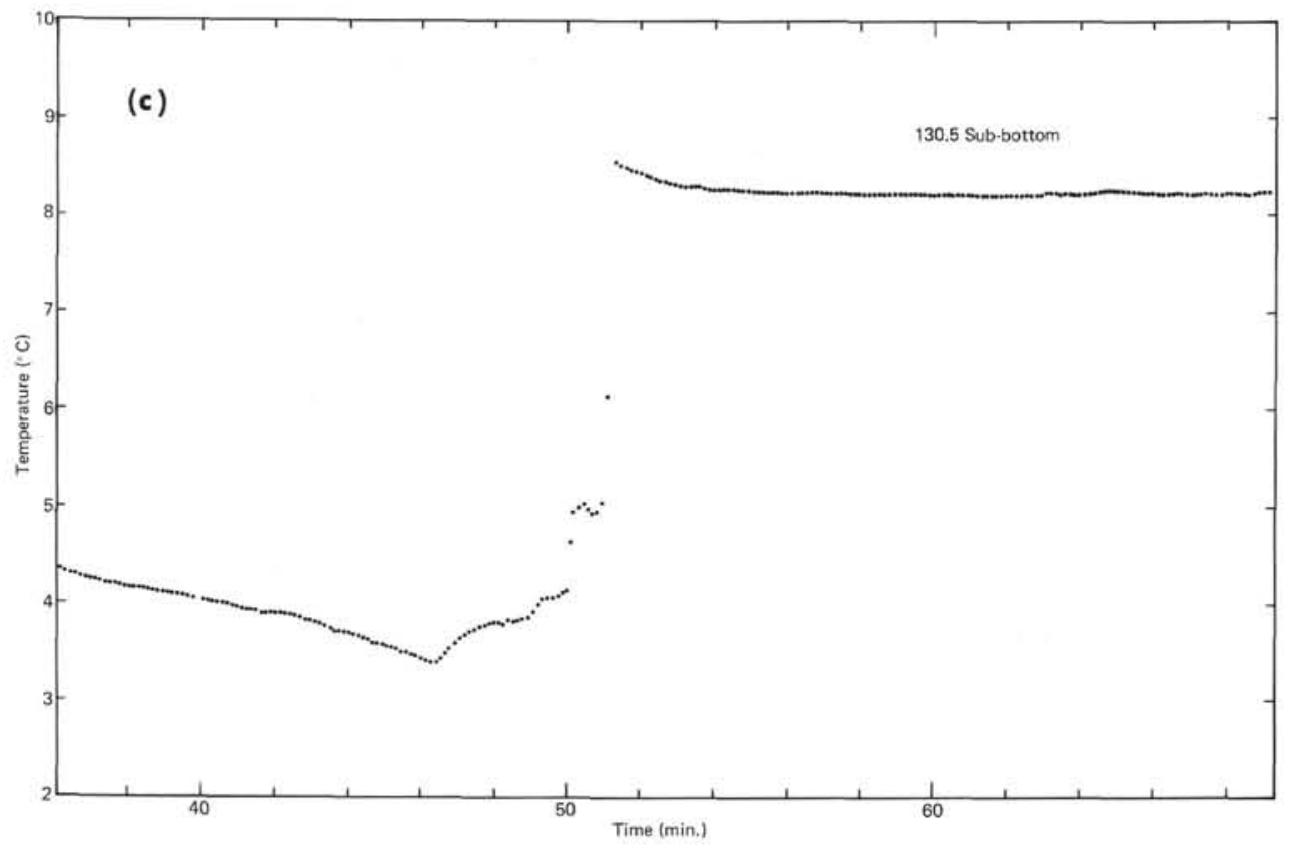

Figure 2. Continued. 
A. J. ERICKSON, W. E. AVERA, R. BYRNE

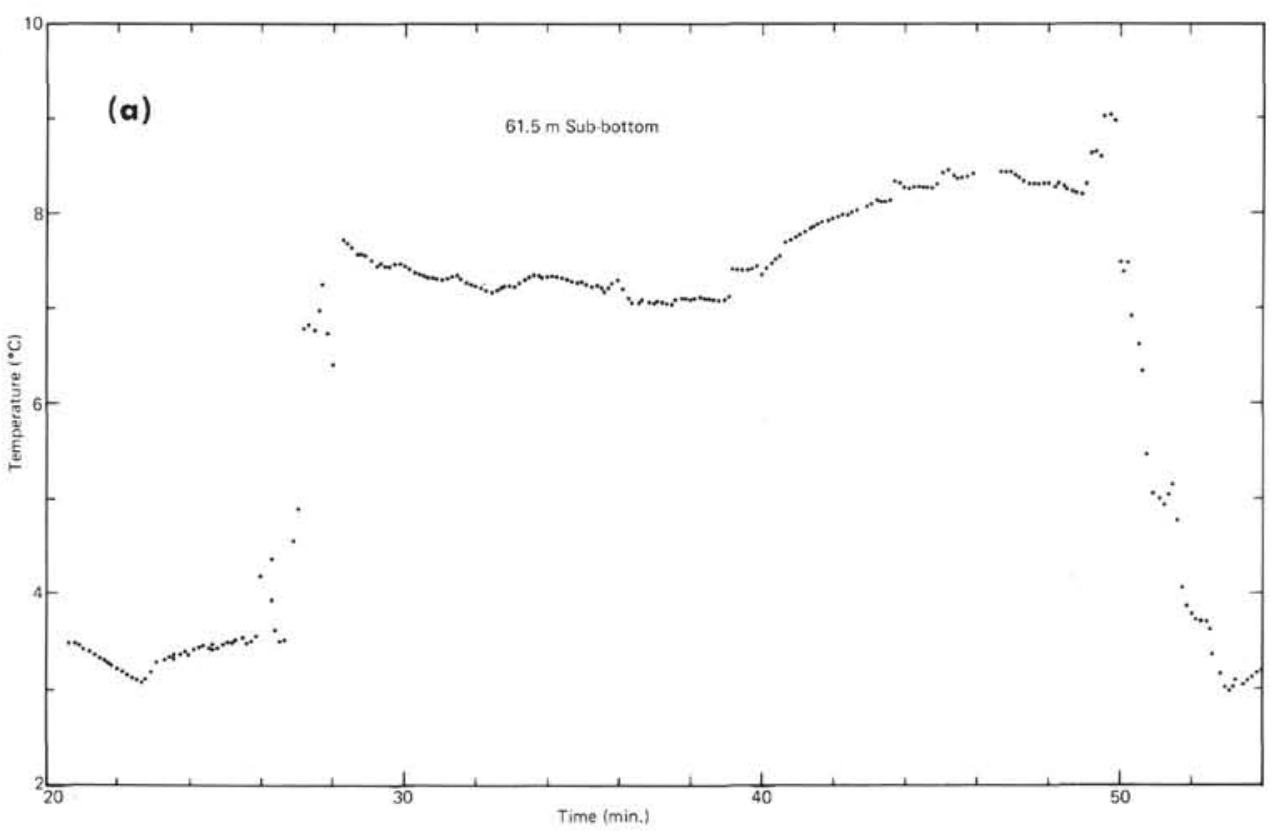

Figure 3. (a-e) Plot of recorded temperature versus time during the downhole temperature measurements at Site 403.

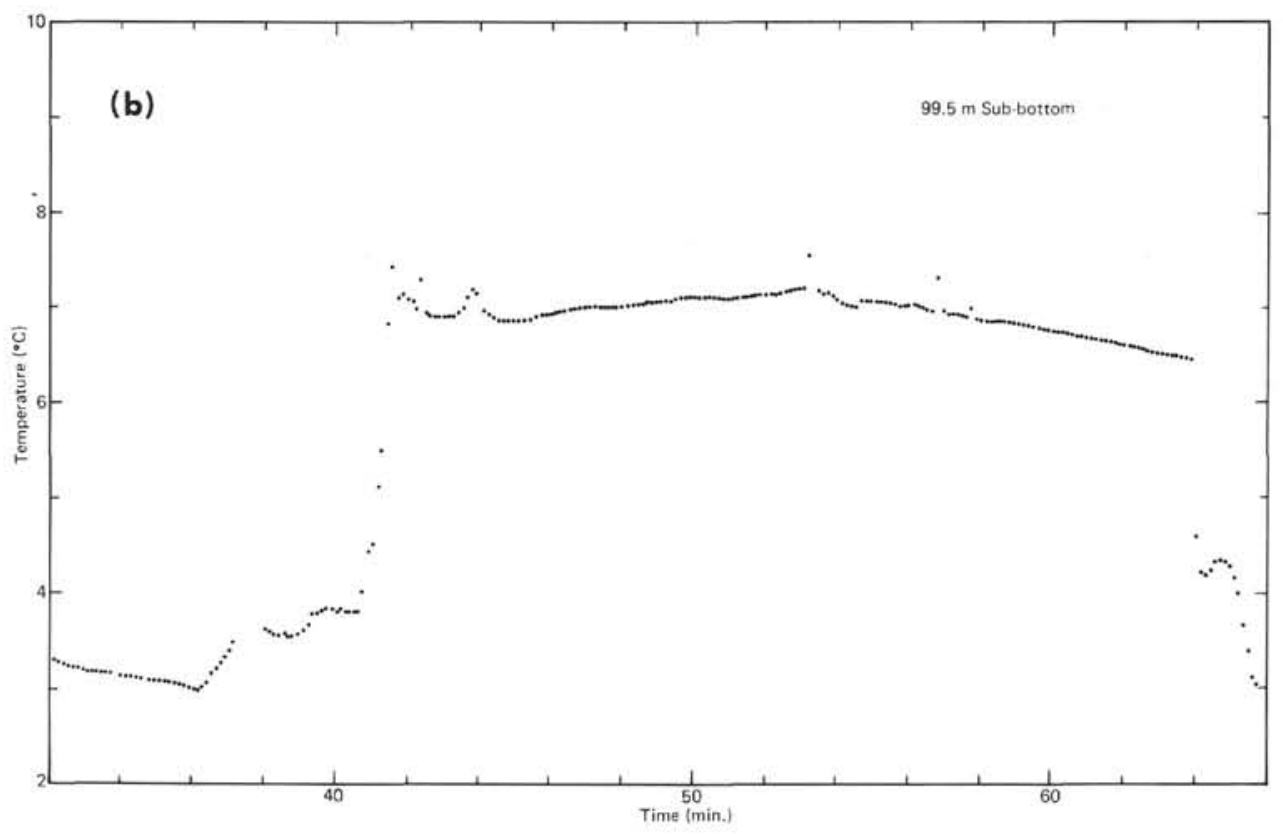

Figure 3. Continued. 
HEAT-FLOW RESULTS

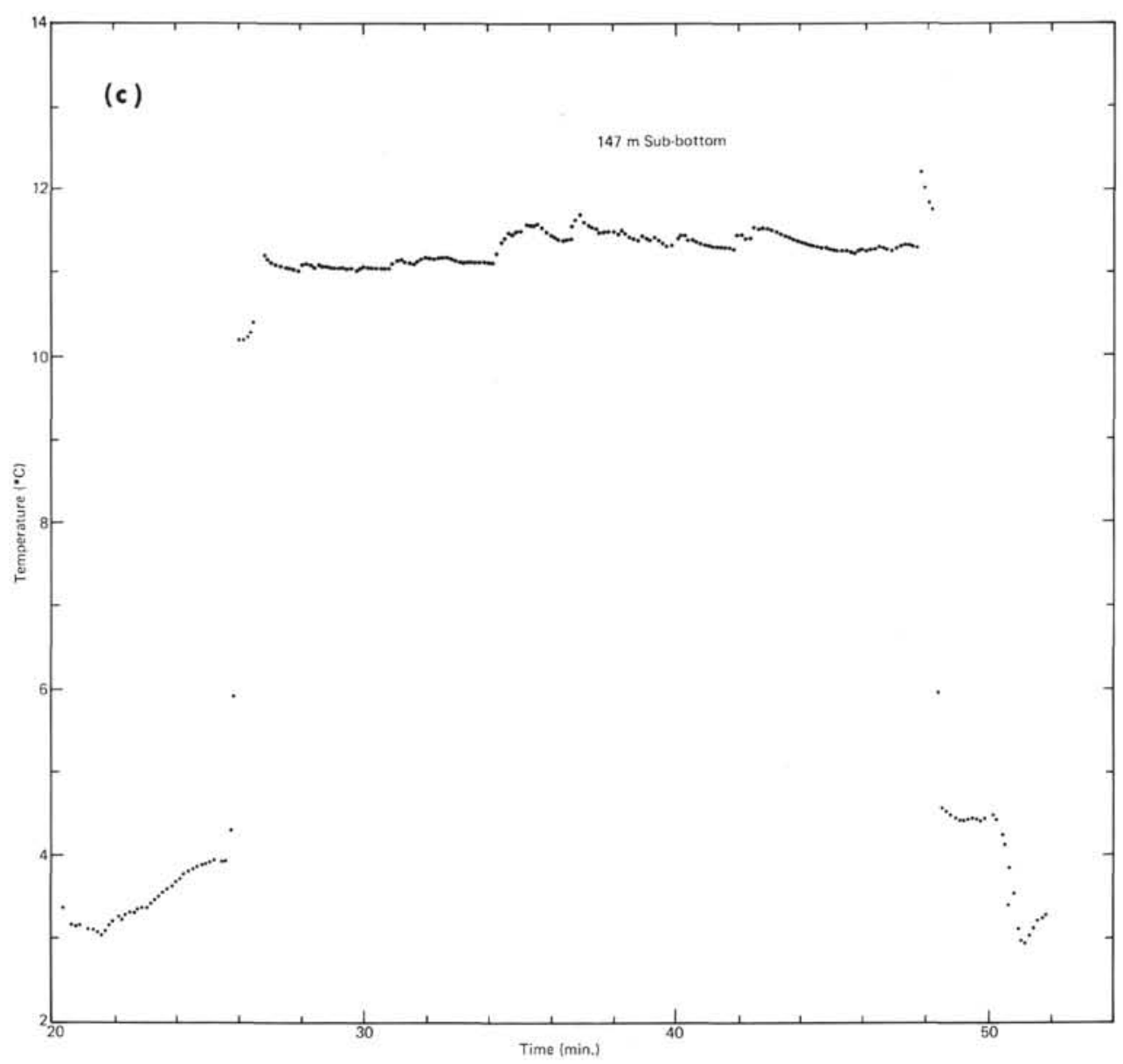

Figure 3. Continued.

283 
A. J. ERICKSON, W.E. AVERA, R. BYRNE

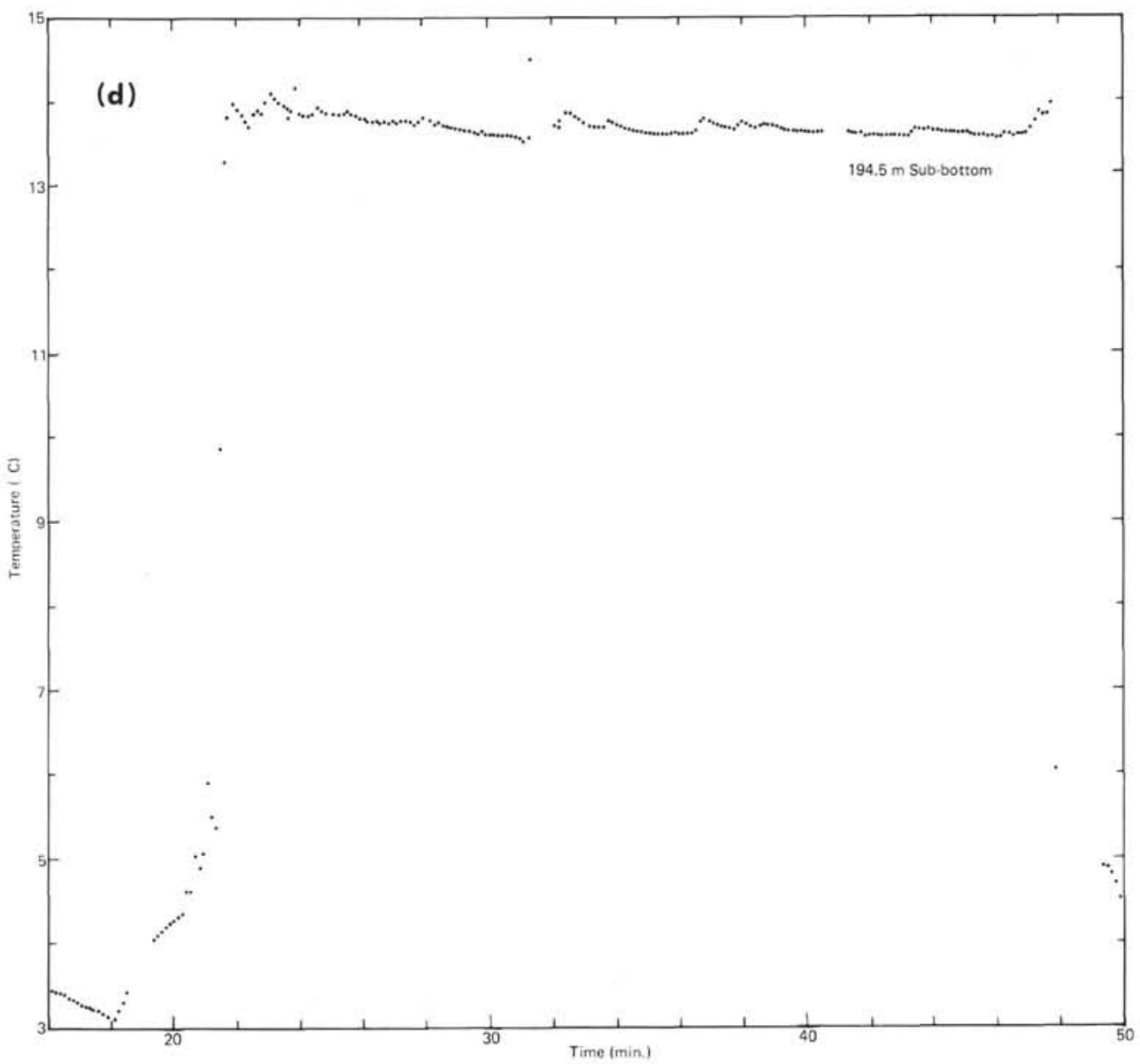

Figure 3. Continued. 


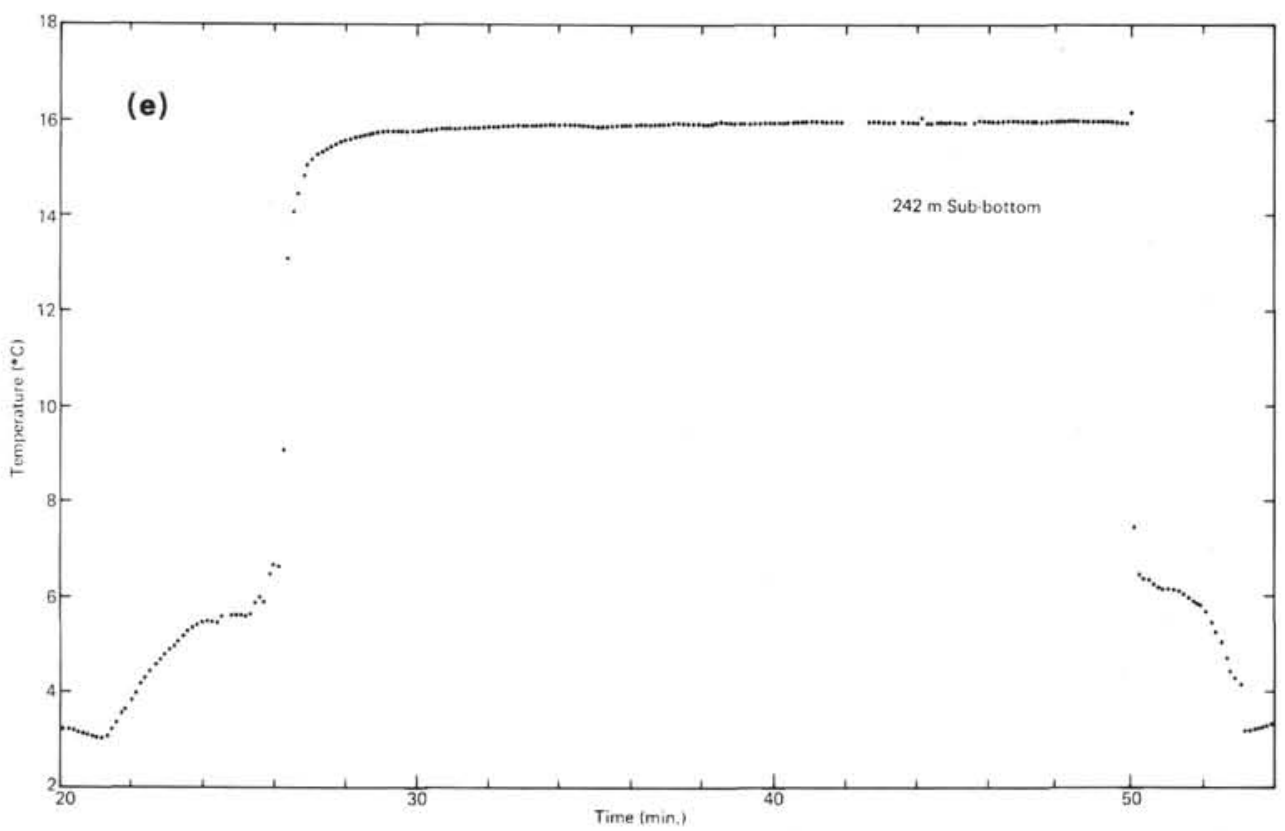

Figure 3. Continued.

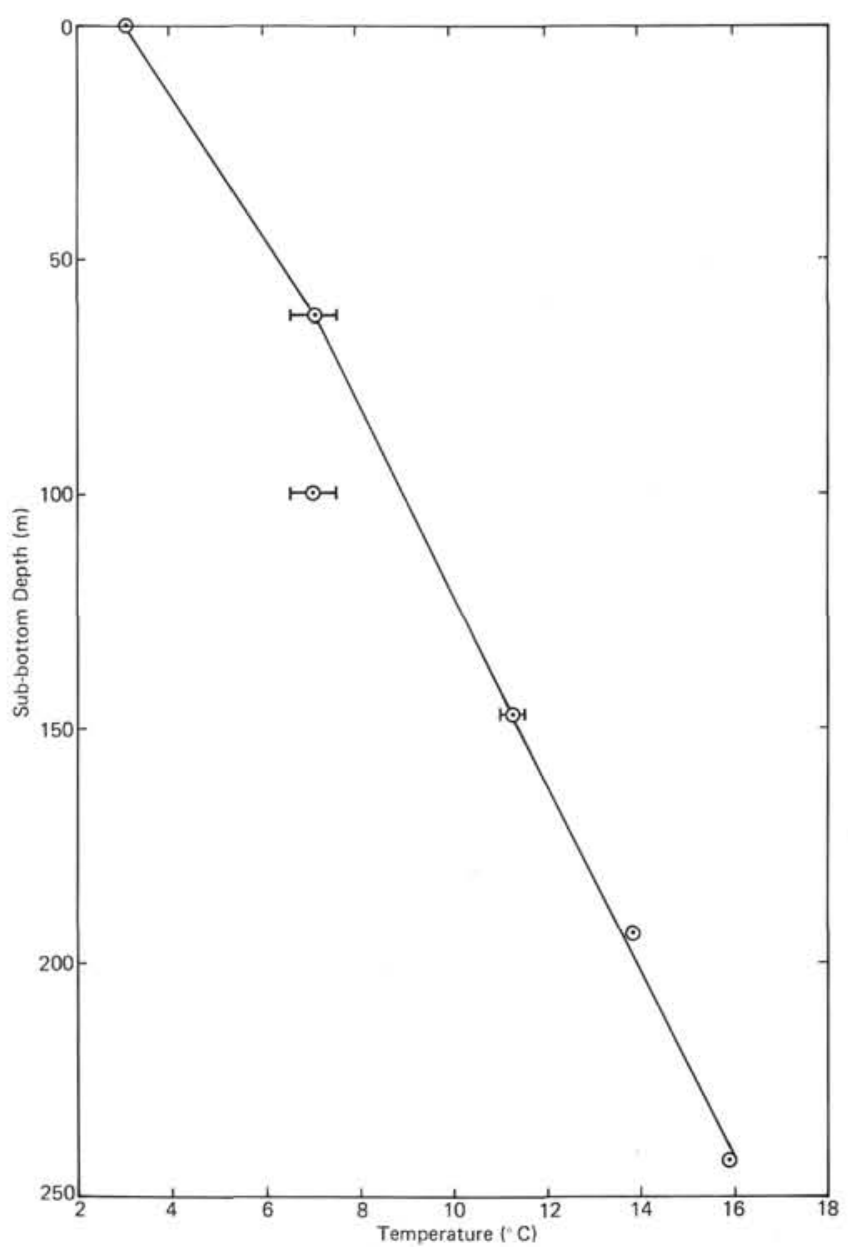

Figure 4. Plot of downhole temperature versus sub-bottom depth at DSDP Site 403. 


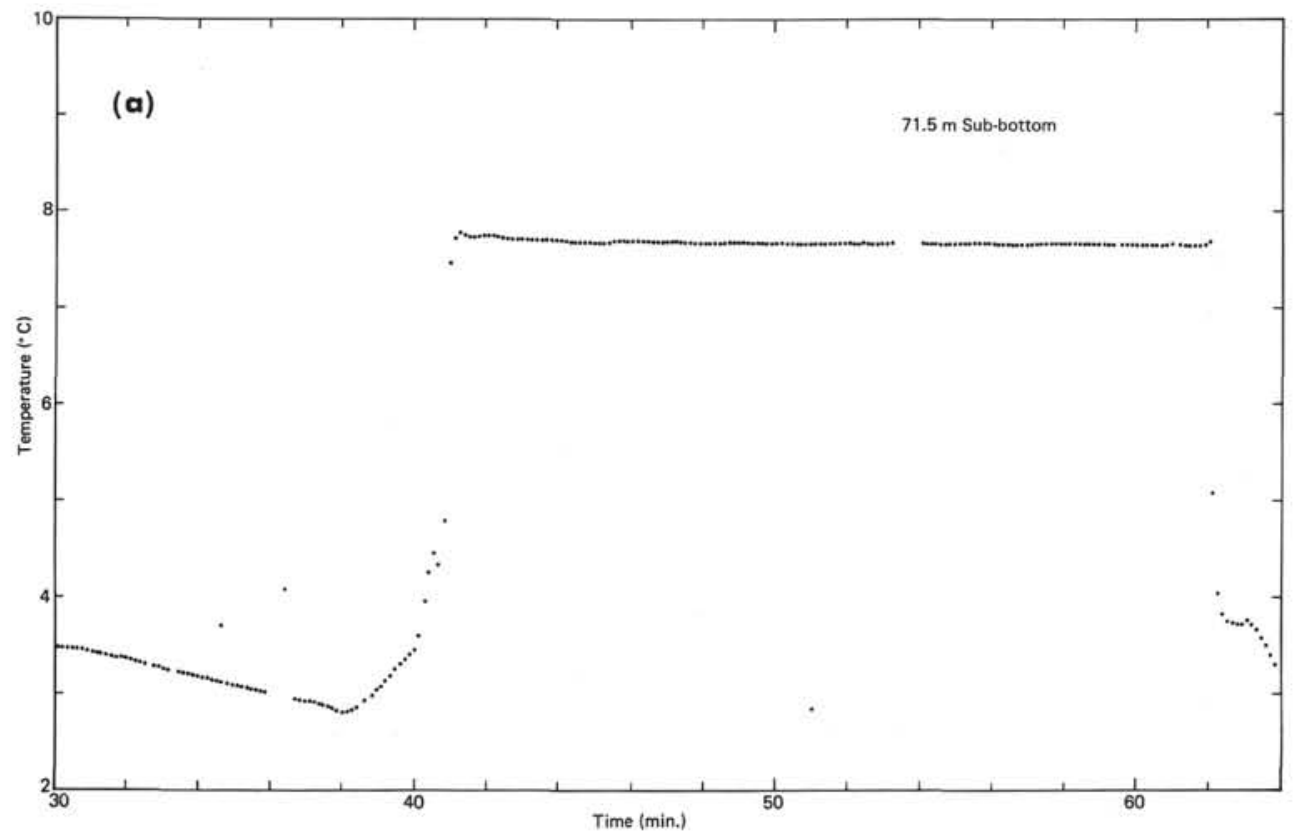

Figure 5. (a-e) Plot of recorded temperature versus time during the downhole temperature measurements at Site 406.

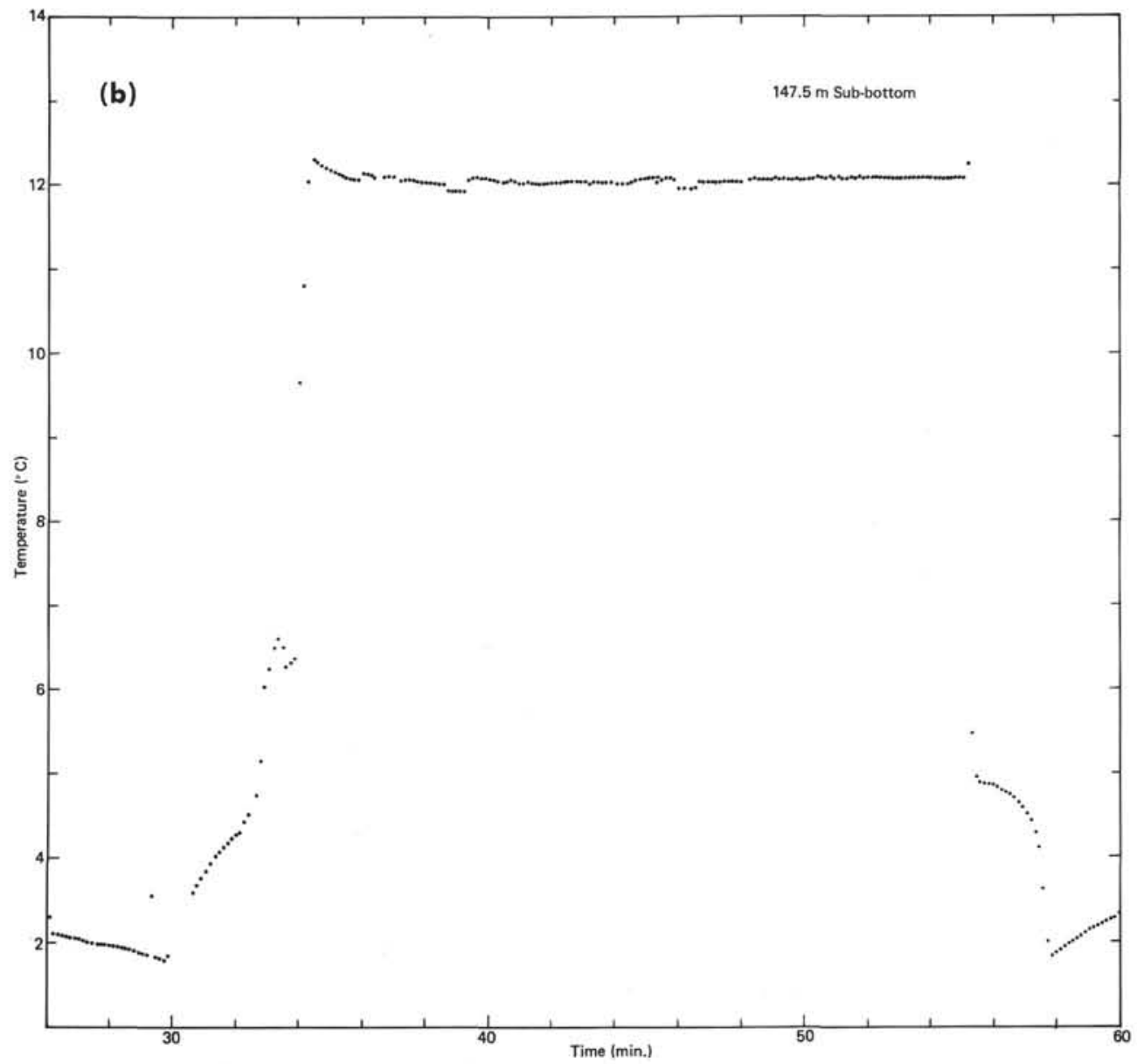

Figure 5. Continued. 


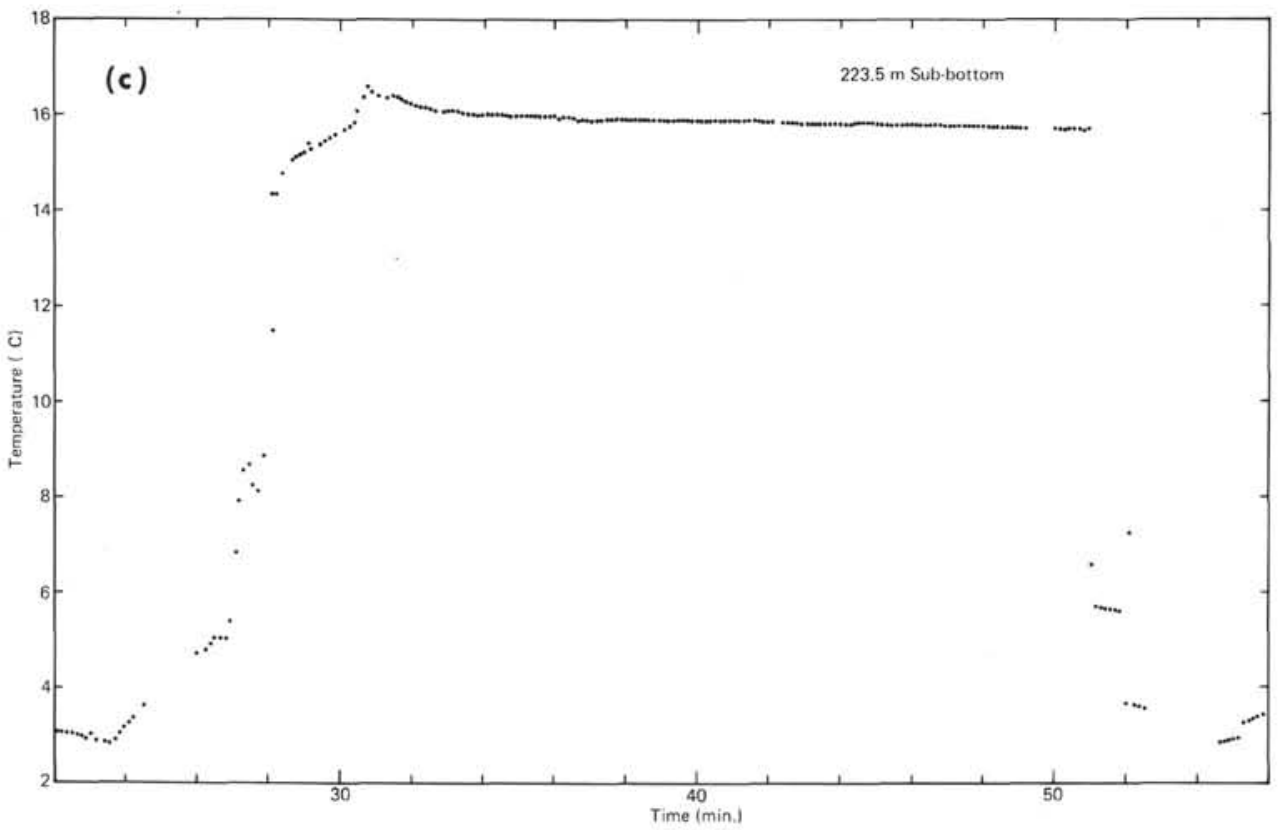

Figure 5. Continued.

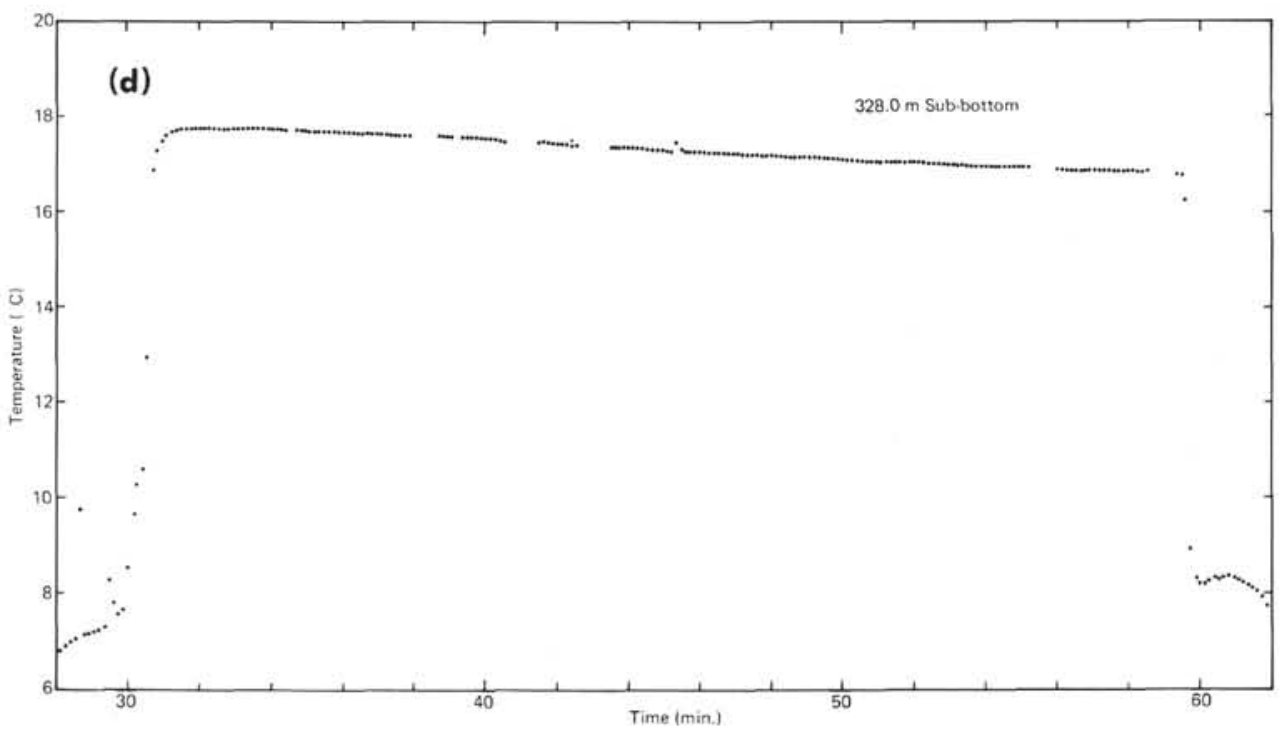

Figure 5. Continued. 


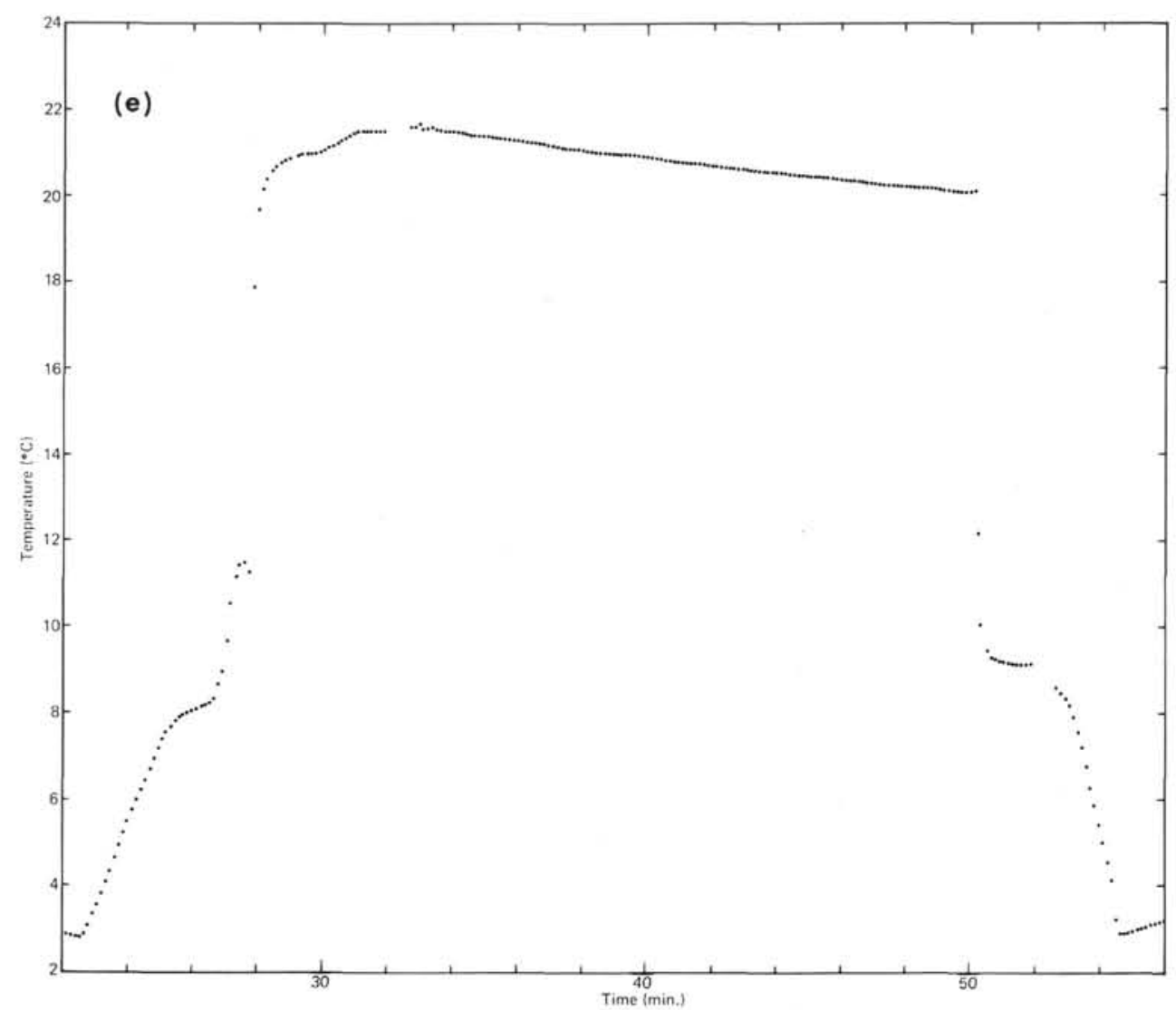

Figure 5. Continued.

TABLE 4

Downhole Temperature Data Obtained in Hole 406

\begin{tabular}{rrl}
\hline Depth $(\mathrm{m})$ & \multicolumn{1}{c}{ Temp. $\left({ }^{\circ} \mathrm{C}\right)$} & \multicolumn{1}{c}{ Remarks } \\
\hline $0.0 \pm 5.0$ & $2.82 \pm 0.05$ & Measured in drill pipe \\
$71.5 \pm 1.0$ & $7.66 \pm 0.02$ & Excellent \\
$147.5 \pm 1.0$ & $12.05 \pm 0.05$ & Excellent \\
$223.5 \pm 1.0$ & $15.94 \pm 0.10$ & Slow cooling \\
$328.0 \pm 1.0$ & $17.70 \pm 0.10$ & Moderate cooling \\
$423.0 \pm 1.0$ & $21.0 \pm 0.50$ & Rapid cooling \\
\hline
\end{tabular}

TABLE 5

Summary of Downhole Heat-Flow Values Determined During DSDP Leg 48

\begin{tabular}{|c|c|c|c|c|c|c|}
\hline \multirow[b]{2}{*}{ Site } & \multicolumn{2}{|c|}{ Position } & \multirow{2}{*}{$\begin{array}{l}\text { Water } \\
\text { Depth }(m)\end{array}$} & \multirow{2}{*}{$\begin{array}{l}\text { Gradient } \\
\left({ }^{\circ} \mathrm{C} / \mathrm{km}\right)\end{array}$} & \multirow{2}{*}{$\begin{array}{c}\text { Conductivity } \\
\left(\mathrm{mcal} / \mathrm{cm}^{2} \sec ^{\circ} \mathrm{C} \text { ) }\right.\end{array}$} & \multirow{2}{*}{$\begin{array}{r}\text { Heat Flow } \\
\left(\mu \mathrm{cal} / \mathrm{cm} 2_{\mathrm{sec})}\right.\end{array}$} \\
\hline & Lat. (N) & Long. (W) & & & & \\
\hline 402 & $47^{\circ} 52.48^{\prime}$ & $8^{\circ} 50.44^{\prime}$ & 2339 & $28.5 \pm 9.5$ & $3.02 \pm 0.18$ & $0.86 \pm 0.34$ \\
\hline 403 & $56^{\circ} 08.31^{\prime}$ & $23^{\circ} 17.64^{\prime}$ & 2301 & $49.3 \div 3.1$ & $3.09 \pm 0.11$ & $1.52 \pm 0.10$ \\
\hline 406 & $55^{\circ} 15.50^{\prime}$ & $22^{\circ} 05.41^{\prime}$ & 2911 & $57.8 \pm 2.4$ & $2.85 \pm 0.32$ & $1.65+0.25$ \\
\hline
\end{tabular}

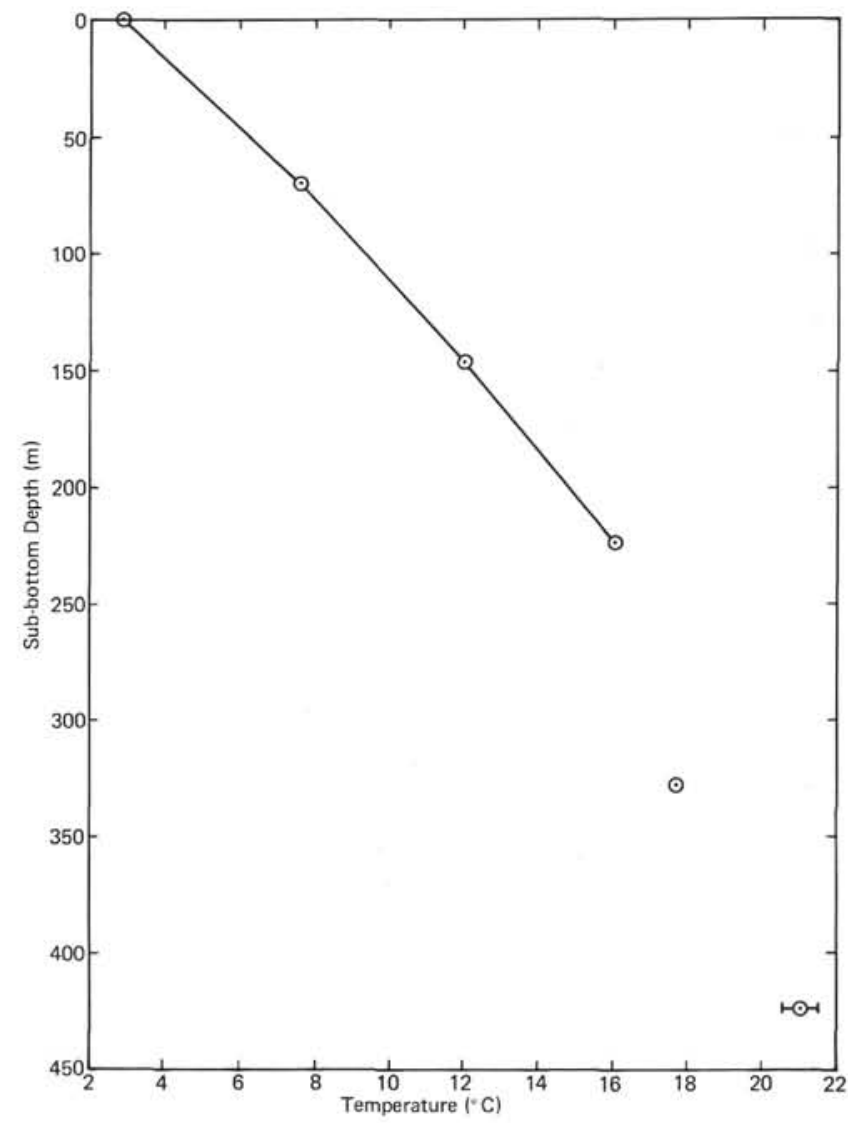

Figure 6. Plot of downhole temperature versus sub-bottom depth at DSDP Site 406. 